\title{
CHILDREN'S AND PARENTS' EXPERIENCES ON EVERYDAY LIFE AND THE HOME/WORK BALANCE IN FINLAND
}

\author{
Taina Kyrönlampi-Kylmänen and Kaarina Määttä
}

\begin{abstract}
Paid work and the high-pressure working life are reflected in the everyday life of Finnish families with children. This article introduces a research project where 29 children aged between 5 and 7 years and their 13 wage-earner parents were interviewed in order to discover to what degree they are able to achieve a home/work balance in their family lives. There is a lack of such research that examines children's and parents' experiences simultaneously and comprehensively, as this study does. The children's experiences were analyzed with an existential-phenomenological method, while the parents' experiences of how their work affects everyday life were interpreted within a hermeneutically advancing interpretation process. This research describes the challenging combination of work and family, the demanding relationship between children and parents, and the ways in which parents approach balancing work and everyday life when parents' paid work, stress, and fatigue follows them home. Parents' working life moulds the rhythm of their children's everyday lives, which are structured by the departures and arrivals at home and at their daycare centers. This article makes visible Finnish families' daily worries and how they cope with everyday life. The research highlights the question of how to secure both children's and parents' rights to a safe and anxiety-free everyday life.
\end{abstract}

Keywords: everyday life, paid work, parenthood, children’s experiences, work/family combination

Correspondence concerning this article should be addressed to: Kaarina Määttä, University of Lapland, Faculty of Education, P.O. Box 122, FI-96101 Rovaniemi, Finland. Email: Kaarina.Maatta@ulapland.fi, tel.+358 400696 480, fax. +358 16362933.

Taina Kyrönlampi-Kylmänen, Ph.D. is Senior Researcher in the project, "Rhythms and Practices in Everyday Life of Families in Transitions", Academy of Finland, University of Helsinki.

Kaarina Määttä, Ph.D. is Professor of Educational Psychology in the Faculty of Education, University of Lapland, Rovaniemi, Finland. 
Everyone is an expert on everyday life. Everyday life is such a familiar concept that many of the daily phenomena, happenings, and operations seem self-evident. Not very often do people have time to question or deliberate that ordinary phenomenon. What we think of as everyday life does not conform to particular boundaries nor is it easy to recognize, which therefore makes it hard to understand just what is being referred to when we discuss everyday life. Conceptualizing and studying everyday life is even more challenging (Felski, 2000; Jokinen, 2005; Tuomi-Gröhn, 2009). As well, discussing everyday life in families is made more complicated by the fact that the notion of family as a concept is multidimensional and can be defined as a group of people affiliated by consanguinity, affinity, or co-residence. However, nowadays, family can refer to a variety of combinations of people varying from the so-called traditional nuclear family with parents and children to singles (e.g., Williams, Sawyer, \& Wahlstrom, 2005). In this article, the word "family" refers to a family unit with children and parents (mother and father) because the families that participated in the original research represented this kind of a family structure.

Today's families with children describe their everyday life as busy: filled with routines, repetition, and cycles. Certain events and happenings take place similarly day after day, week after week, and month after month. Parents' work schedules, children's daycare and school schedules, hobbies, outdoor activities, dining times, and sleeping patterns set the rhythm for everyday life. According to previous research, children experience their everyday life by departures and arrivals as well (Korvela \& Keskinen, 2008; Korvela, 2003; Kyrönlampi-Kylmänen, 2007; Rönkä, Laitinen, \& Malinen, 2009).

Everyday life is often associated with negative images: It is something that one wants to escape from. Adults seem to have the desire to break out from everyday life and its preoccupations, monotony, stress, and their demanding work (Jokinen, 2005). After annual leaves, employees in the coffee breaks of workplaces bemoan the fact that the holidays have ended. For a family, it may be difficult to spend time together on weekdays something that is, on the other hand, possible on holidays.

According to previous studies, parents may feel themselves enslaved by housework and by the routines at home and at work (e.g., Daly, 2003; Korvela \& Keskinen, 2008; Rönkä \& Korvela, 2009). In addition, everyday life is charged with the effort of combining the parents' personal needs with needs of the whole family. The parents of small children wonder how they can find more time for themselves, marriage, children, and hobbies. Nowadays, more and more demands are set for the family and intimate relationships (Karney \& Bradbury, 1995; Määttä, 2005; Sternberg, 1999). Emotional satisfaction, a comfortable emotional atmosphere, and equality are required from family relationships (Määttä, 2006; Uusiautti, 2008; Uusiautti \& Määttä 2010). The increase in the number of divorces reflects, for its part, the increasing demands on the family and intimate relationships (e.g., Gottman, 1994, 1999). From a parent's point of view, everyday life lacks time.

However, various roles enrich everyday life (Clark, 2000). For many families, combining work and family roles is quite painless (Leiter \& Durup, 1996). For example, some of these roles repay the accompanying demands in the form of increased income level, self-esteem, and social success (Barnett \& Hyde, 2001). Thus, after a fulfilling workday, a parent has enough energy to be active with the children even though they have already used significant energy at work. Similarly, a satisfying family life can help with coping at work (Uusiautti \& Määttä, 2010). It is worth remembering that when it comes to the work/family combination, it is not just about "either-or" but 
"both-and" kinds of experiences (Frone, 2003). Nonetheless, it seems that the everyday lives of families sometimes present moments when the demands and needs of various areas of life are on a collision course (Rönkä \& Korvela, 2009; Rönkä et al., 2009).

According to Bronfenbrenner's (1979, 2001) ecological theory, a parent's working life or paid work greatly affects a child's experience of his or her immediate surroundings. A society's legislation, for example labor legislation and daycare system, affects a child's world indirectly through a parent. Thus, the well-being of a child depends primarily on the nature of the growing surroundings provided by his or her parents. The living conditions of an individual family are connected with the general societal living conditions within which the parents have to act (Klein \& White, 1996).

Combining work and family is a continuous issue in labor market negotiations, with political speeches often referring to families with one parent or two parents and children (see Lammi-Taskula, Salmi, \& Parrukoski, 2009; Barling, 1994). The combination of work and family and their symbiotic relationship have become more and more complex. Children's parents have to balance between home and work more than before (Hoschild, 2000; Jallinoja, 2000; Michel \& Hargis, 2008).

One reason for the stirring of this discourse since the 1990s has been an escalating pace of working life that leaves less time for parenting. The other reason for this debate involves how work itself has changed: New technology has made working at home possible and increased the probability of doing so as well. A parent can read e-mail in the evenings and answer work calls (Daly, 2003; Dunom, 2000). People's opportunities to affect their work schedules have increased but, at the same time, working hours lack predictability as employees may be reached at all hours (Dunom, 2000).

\section{The Situation in Finland}

The separation between work and leisure accompanied industrialization in Western societies beginning in the 19th century when parents' everyday life started to be divided between home and paid work outside the home (Klein, Izquierdo, \& Bradbury, 2007; Scott, 2009; Wintersberger, 2000). In Finland, the passage from an agrarian society into an industrial one took place after the Second World War. People moved from the countryside to cities in the 1960s and 1970s starting the development into a so-called welfare state in Finland (Korvela \& Keskinen, 2008). Thus, nowadays Finland uses Nordic welfare state principles and methods that are based on the state's responsibility for its citizens. Welfare services, such as Early Childhood Education and Care (ECEC), are arranged and funded by central and local government. Daycare services are open for every child or in other words, all children below school age are entitled to receive municipal daycare. There are also private daycare services available with different costs (Heinämäki, 2008).

In Finland, there are a variety of family policy activities, services, and benefits available (see The Social Insurance Institution of Finland KELA, www.kela.fi): Before and after childbirth, mothers (and children) use the services of maternity and child welfare clinics. Leaves related to childbirth begin with mothers starting their maternity leave at the earliest 50 days and at the latest 30 days before the expected date of delivery. After that, either the mother or the father can have a parental leave (Parental Allowance is funded for 158 working days) or they can share it. In addition, fathers can take between one and 18 days of paternity leave after childbirth in order to look after 
their child at home together with the mother. All the leaves are funded by the Social Insurance Institution of Finland. After parental allowance or extended paternity allowance, parents can take a childcare leave with full employment security to look after a child under age 3, though both parents cannot be on full-time leave at the same time (Heinämäki, 2008; Official Statistics of Finland, 2009). All children in Finland have to go to school at age 7. School begins at the start of the autumn semester at primary school and the nine-year-long compulsory education is free for all pupils. Finnish children have the right to participate in voluntary and free preschool education during the year preceding compulsory education (Official Statistics of Finland, 2009).

\section{The Aim of This Article}

In the public discourse, everyday life - or at least the contemplation of it - is present in the current era. Politicians, educational professionals, researchers, and teachers as well as the representatives of the church and various associations write and talk about the meaning of everyday life. Emphasizing its significance partly shows that people's daily behavior is subject to increasing concern. Although various academic disciplines have focused more and more on children's opinions on matters directly affecting them, the effect of parents' work on the everyday life experiences of preschool-aged children are still studied relatively scarcely; in particular, there is a lack of such research that would study children's and parents' experiences simultaneously and comprehensively.

The aim of this article is to describe children's and parents' experiences on the balance between the parents' work and everyday life at home. The following research questions are set to guide this study:

1. How do the working parents describe the combination of work and family?

2. How do the working parents describe their relationship with their children?

3. How do the children of the working parents describe their everyday life?

As a conclusion, what the parents and children really say will be discussed: What do the results reveal about the situation of today's Finnish families and their struggle between work-related and family-related expectations.

\section{Research Data and Methods}

The empirical data of this research was collected in northern Finland during the spring of 2003; 29 children (14 girls and 15 boys) between 5 and 7 years of age and 13 of their parents (seven mothers and six fathers) participated in the research. The parents' professional positions varied but what they had in common was that all of them worked outside the home. The children spent their weekdays at a daycare center. The children were invited from three different municipal daycare centers in Rovaniemi, a dynamic and growing city with a current population of 60,000 people located on the Arctic Circle in northern Finland. The participants were selected based on their willingness to participate in the research.

The research data was acquired from three different daycare centers, where the first author spent abundant time before carrying out the interviews. The researcher-adult became familiar to the children. As time went on, the children noticed the difference between the researcher and the staff in the daycare center. From the children's perspective, the researcher was someone who spent time 
with them but still did not have an educative or authoritative relationship with them. Before carrying out the interviews with the children, permission was obtained from both the children's parents and other partners in cooperation with the daycare center. When designing the research interviews, the questions had to be carefully formulated and phrased so that they would not be too difficult, problematic, or stressful for a child.

Inquiries about the children's and parents' experiences were placed through a semistructured interview. The themes for the child interviews were the following: "The Child's Family"; "The Child's Day at the Daycare Center"; "The Parent's Work"; and "Being Together with the Parent". Respectively, the themes for the parent interviews were the following: "Our Family"; "The Parent's Work"; "Being Together with the Child”; “The Child's Daycare History”; "Experiences of Daycare"; "The Rhythm of Everyday Life"; and "The Social Net". All the interviews were recorded and then written up. Altogether, the transcript consisted of about 500 pages. The interviews varied between 30 minutes to two hours in length. The children were interviewed at their daycare center and the parents at their home, one individual at a time.

The children's experiences were analyzed with an existential-phenomenological method. This method wants to be loyal to the phenomenon under study and aims to observe the phenomenon as open-mindedly as possible. The existential-phenomenological analyzing method utilized in this research is based especially on Giorgi's (1994) phenomenological research method (KyrönlampiKylmänen, 2007). The parents' experiences of how their work affects everyday life are interpreted within a hermeneutically advancing interpretation process. This kind of interpretation process pursues analyzing the experiences with reconstructive methods; in practice, it means structuring, explicating, and condensing the interview data. Furthermore, the conclusions made based on the analyses and interpretations are always compared with the original data (Latomaa, 2005; van Manen, 2002; see also Gadamer, 2004).

The analysis also brought out and highlighted the special nature of carrying out child interviews, as well as the challenges of understanding the children's world. We will evaluate the interview process at the end of this article but we have also discussed these issues in greater detail in our previous publications (Kyrönlampi-Kylmänen, 2007; Kyrönlampi-Kylmänen \& Määttä, 2010).

\section{Results}

\section{How Do the Working Parents Describe the Combination of Work and Family?}

Looking for balance. According to the parents participating in this research, the most challenging moments in their family life often concerned the difficulties of adjusting family life to the demands of working life and other areas of life, such as hobbies and social networking (see also Daly, 2003; Jokinen, 2005; Korvela, 2003; Rönkä \& Korvela, 2009). The parents thought they had too little time to spend together with their children during the week, as one mother pointed out: "We should have more time for cuddling".

Working outside the home is more common in families with children than in other households in Finland. The fathers of small children work more overtime, on average, than other men and this pattern persists regardless of the age of their children. Every third child's mother works irregular hours (for example, shift work or weekends). Considering the time spent in paid 
work and housework, the parents of preschool-aged children are the most encumbered (Lainiala, 2010; Pulkkinen, 2002; Sauli \& Kainulainen, 2001).

The research data showed especially that full-time jobs took plenty of time from a weekday. One dad described what kinds of conflicts balancing the combination of work and family life can cause: "When the children are small, you could be more at home. I have really tried to be more and more but I also think that I have to work long hours". Most of the small children's fathers thought their work took too much time from their family life. This fact can actually cause regret later on in a parent's life (see Paajanen, 2007).

The mothers in this study adjusted their working hours and duties to the needs of family life and everyday situations more than fathers did (see also Dunom, 2000; Lainiala, 2010) and tended to give priority to the family more frequently than the fathers. The families preferred a traditional role model, according to which the women's duty is to take care of the children and home whereas the men's duty is to earn a living (Dunom, 2000). The mothers thought that responsible motherhood required togetherness with a child (cf., Sevon, 2009). The families' everyday tasks and time management were mostly the mothers' responsibility. In this research, the mothers tended to be more flexible concerning their work duties rather than with respect to the time spent together with their families and children.

Two of the interviewed mothers had resigned directorships in order to devote more time to family, children, and parenthood. "So, I have tried to work as a manager but combining working life and family in that sector is really hard; and for women especially. You see, I like to fuss with my children in the evenings a lot..." (cf., Bowes, 1998). On the other hand, the fathers who worked as managers thought that their work was interesting and did not consider changing the content of their work or reducing their working hours. The satisfaction they gained from the paid work was considered more important.

Although $70 \%$ of Finnish women work, the attitudes in our society do not necessarily support women's careers and female leadership. It is common for Finnish women to work in occupations where the majority of employees are female, while Finnish men work in male-oriented work communities. There are fewer female than male business managers, especially at the highest levels of decision-making. The glass ceiling phenomenon refers to the invisible obstacle between the highest level of decision-making and women. In this research, women's careers that included managerial work generally were restricted to decision-making within the families. It is perhaps worth asking whether the opportunities for women provided by society are replicated inside a family from the perspective of women's careers (see also Aaltio-Marjosola, 2001; Donati, 2000; Klein \& White, 1996).

In this study, the parents did not have part-time jobs because having one was considered an economically impossible option (cf., Hayes \& Watt, 1998). Nonetheless, a part-time job was a dream for one mother: "I would like to be at home at least the next fall when my son goes to the first grade. It is my dream and I can't live on relief because the benefit is so small that I can't pay the loans with it... [I would like to] take them to school and walk with them to the bus stop to wait for [the school transportation]. I would like to do that... it is my dream but I know that it won't come true anymore”. 
In Finland, the housewife tradition has not been well established because industrialization took place quite late compared to other Western societies. Furthermore, working life has not been separated from home as strongly as in some other parts of Europe; nor has the culture of part-time working been regularized. Even if part-time work would make the parents' everyday life easier, it appeared merely as a dream, especially among the mothers interviewed in this research. The participating fathers did not have the same kinds of dreams as they seemed to consider a full-time job as a matter of course.

The parents' work-related issues bother the everyday life at home. Unpredictable working hours cause problems for the family's everyday life. Several everyday routines are time-bound: picking up the children from the daycare at a certain time, going to the grocery store, preparing dinner, the children's bedtime, and so on. Work may also follow parents home in their thoughts. Working at home after-hours changes everyday routines. Naturally, this bothers the children as the following example related by a 6-year-old girl shows: "My dad is always there at the computer... yeah, he does the paper work and tells us to shut up when he's on the phone".

In this study, the children considered home a place where their parents would be present for them, where they would not have to be share their parents with the parents' work. Some children seemed almost "jealous" of a parent's work if work took time and a prominent place in the home environment. The children defined home as a place where work-related matters do not belong (e.g., Bowes, 1998; Daly, 2003; Kyrönlampi-Kylmänen \& Määttä, 2010).

Rouvinen's (2007) research showed how kindergarten teachers think parents concentrate too much on their own work, among other things, and do not have enough time to concentrate on rearing their children. According to kindergarten teachers, working life interferes with child rearing because it involves the families in a busy lifestyle with a lack of time for togetherness. Further, these teachers thought that parents liked their work almost too much because at work they could receive recognition (see also Hochschild, 2001). Some of the kindergarten teachers claimed that the parents had more interest in ascending their own career ladder than in their own children (Rouvinen, 2007). Noteworthy, however, is the fact that at least this phenomenon did not occur among the mothers in this study.

From the perspective of time management, combining work and family was already considered challenging, but the instability of working life and worries about the possibility of underemployment, or even unemployment, add extra challenges. The problems in the work/family combination were often related not only to the lack of time but also to lack of money. In this research, the parents were concerned with whether they had sufficient money. One father stated, "It is possible that it would make the children suffer if we didn't have money to buy gear and odds and ends. I just realized when the school started that there is quite a pressure for it at school". Indeed, several studies have proved that Finnish families with children have relatively weak social status. In Finland, approximately $70 \%$ of the incomes of families with preschool children go into food and housing (e.g., Blom, 2001; Hujala \& Kyrönlampi-Kymänen, 2003). This is how economic prerequisites determine the rhythm of everyday life and cause people to make choices (such as the one between full-time and part-time work). In this study, the children did not worry about the sufficiency of money in their family, nor did they bring up their materialistic hopes or claims. Apparently, the livelihood of the families in this research was at an adequate level. 
Similarly, the hectic characteristics of the parents’ demanding work schedules, as well as all the 24/7 operations and services that often accompany them, followed the parents home and thus affected the nature of the "family time". It has been pointed out that because of, for example, an unexpected firing or furlough, the mutual time for parents and children in a family may be increased but at the same time subverted by concern about the future that exasperates parents, thus affecting the atmosphere at home as well as the quality of interactions between children and parents. It is necessary - although not sufficient as such - for a child and a parent to spend time together in order to create a caring atmosphere at home. A family may realize this after a firing (Haverinen \& Martikainen, 2004; Rönkä \& Korvela, 2009).

\section{How Do the Working Parents Describe Their Relationship with Their Children?}

The parents transmitted their work-related stress and anxiety into their children's world. Indeed, even a small baby is capable of sensing and noticing a parent's moods (Bowes, 1998; Hayes \& Watt, 1998; Näsman, 2003; Stern, 1997). The children were aware of how working life made their parents exhausted thereby detracting from their time together. The children proved to be sensitive in recognizing their parents' moods. A 6-year-old girl observed, "Well, she [mom] doesn't ever play with us or watch TV but dad sometimes does. He would always watch TV on the couch and mom would tell him to clean the table with me and he would always just watch that TV there".

The parents reported they felt exhausted after a workday, as did the children after a daycare day as well. Often, the parents had the added strain of completing unfinished work tasks at home. According to the interviews, the tired and busy parents found it difficult to concentrate on the children and their needs. When the parents felt tired, they were impatient; nor did they have the strength to confront the children's anger. One father noted, "But when you feel really exhausted, the child can provoke you and certainly knows how to make a parent really angry". The parents expressed how sorry they felt after getting angry with a child and for their inconsistent child rearing in general. The concern over this situation was amplified when the child was also tired after a day spent at daycare. This can easily lead to conflicts and clashes between a child and a parent. Fatigue on the part of both parent and child and the arguments caused by it were of great concern for the parents.

The children were tired in the mornings at the time of going to daycare. They found this tiredness uncomfortable and unwanted. Those children who attended daycare part-time were more satisfied with the everyday rhythm and their amount of sleep. A 6-year-old boy thought: "It is a fitting day by its length...”. The children experienced insufficient rest as uncomfortable. Deficient sleep causes headache, restlessness, and concentration difficulties for a child. Sufficient good quality sleep improves the body's immune system, focuses the ability to learn and concentrate, as well as maintaining the healthy fuctioning of the central nervous system. Adequate sleep is salient for a child's well-being, growth, and health (see Siren-Tiusanen \& Tiusanen, 2001). The data in this study implies that a parent's full-time work affects a child's well-being and vigor, particularly after a daycare day during the weekdays.

One of the dads noted: "[I'm] present physically but my thoughts are elsewhere". This statement illustrates how parents and children may spend time together but still inhabit worlds of their own. Korvela (2003) refers to the tension of acting together and separately (p. 145). Children easily recognize if a parent's mind is straying at home or if parents do not concentrate on playing together with them. In these situations, the children may bend and continue playing either alone or 
with a sibling or a friend. Working life affects family life and vice versa (e.g., Bowes, 1998; Hayes \& Watt, 1998; Rönkä \& Korvela, 2009). Trouble either at work or in the family life is reflected in the relationship between parent and child. This phenomenon is illustrated by one mother's utterance: "At the times, when it is extremely hard both at work and in private life, it surely takes enormous amounts of your strength to handle it. I have to admit that I have been quite tired".

The changing situations in family life seemed to affect work most when a child was sick. Then, the family has to solve the daycare problem because a sick child cannot go to the daycare center. It is not necessarily easy for a small child's parents to be absent from work although they have a legal right in Finland to do so (see Reuna, 1999). Some employers seem to be dead set against a parent staying at home to take care of a sick child. Naturally, an employer's inflexible attitude makes a parent feel concern and guilt. A participating mother discusses this dilemma:

We have to present the medical certificates. And that too, I call it a snooping note, because they ask where my husband will work and at what time; and they require a signature from his boss... to ensure that we won't be at home at the same time. Because I'm like that, if you have to be out of work a lot because children are often sick one after the other, and yourself as well, then I have a bad conscience.

Relaxed time together in the weeknights may remain minimal for working parents and children. After preparing dinner and doing housework, it is already so late that there is no time for shared activities. The weekday mornings are busy and even chaotic: "Where are your socks?”; “Won't you hurry up now, will you?”. It may be difficult for a child to wake up instantly and a parent's patience is tested when trying to get the child awake. From a child's point of view, the reason for this is the hurry and stress caused by a parent's work (see also Kyrönlampi-Kylmänen \& Määttä, 2010).

\section{How Do the Children of the Working Parents Describe Their Everyday Life?}

The way the children describe the parents' work. Most of the children in this study had a well-defined conception of their parents' work. The more concrete a parent's job description was, the easier it was for the children to understand it. In addition, if a child had visited his or her parent's place of employment, the child found it easier to understand what the parent did for a living, as the following conversation with a 6-year-old girl illustrates:

I: Where does your mom work?

G: At a hospital.

I: What does she do there?

$G$ : She is a hospital attendant.

I: Have you visited your mom's workplace?

G: Oh yes... when I left my toe under a bench. It was flattened and got a little bit squashed and it was all black.

Those children who had not visited a parent's workplace or did not find a parent's work description as concrete seemed to have difficulties understanding the content of the parent's work. In the next example, another 6-year-old girl thinks of her mother's work duties: "She [mom] is a manager somewhere... bosses others... bosses around like this and that... at least they count money there at the workplace... my mom's". Furthermore, a child does not always find it easy to answer an 
adult’s questions (cf., Kyrönlampi-Kylmänen, 2007), as a 6-year-old girl answers in the following example:

\section{I: Where does your dad work? \\ G: Well, he is there, far away.}

One child remembered all the things that seemed funny, exciting, and special at his parent's workplace, such as the coffee machine, stairs, elevators, and extraordinary objects like cable reels. The child described the parent's workplace in the following manner: "Well, there are those weird stairs and a sort of elevator. And then, all the doors are opened in a sort of funny way by pushing a button. I always like to push buttons. The one who pushes it will get in".

Respectively, the parents related that they are aware that most of the children know what the parents do for living. Those parents whose work even adults find hard to understand knew that the children did not understand what they were doing for work. Several parents who worked in the electronics industry stated that they are not allowed to talk about their work in detail.

The rhythm of everyday life - a child's perspective. Everyday life in families is moving constantly and always subject to change. Everyday life in families consists of daily emotional transfer and a spectrum of various feelings. Everyday life in families involves creating an atmosphere, arranging and combining practicalities and schedules (Perlow, 1997, 1999).

Nowadays, most Finns do not have to fight against the forces of nature as they did 50 years ago. Today, for example, basic groceries can be found in the store and we have enough warm water for laundering. Instead, modern everyday life struggles are more likely to concern a problem like combining work and family, as well as other areas of life, or having enough time for the activities that are considered important (Daly, 2003; Freeman \& Louca, 2001; Rönkä \& Korvela, 2009). Even a child (in this case a 6-year-old boy) distinguished two different worlds in everyday life: "Well, I guess it is like leisure. You can act a little bit freely. Five days of preschool and two days off'. What was this child talking about? His statement revealed the way he experienced the difference between work and leisure in everyday life: Daycare and school took time away from his free time.

Everyday routines and rhythms are crucial for people's well-being (Felski, 2000). Often a lack of these routines causes problems for children and youth. It is an adult's responsibility to create the routines in a child's life. Routines and repetition make a child's everyday life familiar and safe because repetition is the supporting structure of everyday life. Predictability and repetition of activities frees energy and time for other tasks (see Korvela, 2003). In child rearing, it is important to realize the role of daily routines in the experience of a meaningful life. Effective everyday life includes the parents initiating and handling daily routines such as cleaning, laundering, going to the grocery store, eating, outdoor activities, and children's basic care. However, this is not always the case for every family or in every instance. If the everyday life lacks a regular structure, it will cause a child to have feelings of insecurity, as illustrated by the 7-year-old boy narrating the following example: "we always stay up late. I guess we set a record. Because even the neighbors go to sleep at 7:00 p.m. but we still make a fuss at home all the time, so the neighbors probably wake up too".

Everyday life that lacks regularity and routine is chaotic and unpredictable from the perspectives of both child and parent. Previous studies have shown how a disordered and chaotic 
everyday life increases children's disruptive behavior, influences a child's health (for example, as arterial hypertension), weakens a child's social skills and ability to play collaboratively, as well as slows down linguistic development (Korvela 2003; Korvela \& Keskinen, 2008). This indicates that the significance of a controlled daily rhythm of life in families with children cannot be overstated.

A child's everyday life follows the basic rhythm of his or her significant adults; the changes in the adults' everyday life are reflected in the child's everyday life. Similarly, adult anxiety is transmitted to children. In this study, the children were clear in their opinion that an ordinary, relaxed everyday life is best. According to these children, the highlights of everyday life were things such as being able to play in peace and, at the same time, being able to relax after a busy day at a daycare center. Everyday life reveals the power structures that prevail between adults and children. At speech level, adults express this as "I have the right" whether they refer to daycare, custody, dividing parental leaves between mother and father, visiting rights, or adoption. More rarely, children's rights are discussed (see, for example, Wintersberg, 2000), expressed as, “Well, I want to rest on the bed when I'm tired". How could the preschool-aged children's wishes be realized? They have to wake up at 5.30 a.m. five days a week.

For children, a daycare center represents a place where they are separated from their parents. The time that is shared with a child and a parent can be divided into mutual time at home when a parent is physically present, and the mental time or the remembering time away from home when family members remember each other during the day although they are not physically present and within each other's sight (Gillis, 2003). For children then, the daycare center is also, in part, a place where they have time to reminisce about their parents. Thus, the emotional world at the daycare center is tinted with feelings of longing and yearning for a parent (Kyrönlampi-Kylmänen \& Määttä, 2010).

At some daycare centers in Finland, it has been considered important that the children think back to their parents during their time at daycare. The children therefore always have a picture of their family with them when longing for a parent intensely. The picture helps a child to relieve the emotional anxiety that manifests itself to a child as longing for a parent and as a wish to get back home. In this research, the parents did not talk about the nature of the feelings their children would experience during a daycare day.

\section{Conclusion}

\section{Beyond Children's and Parents' Experiences}

What can be concluded about the results that emerged from the interviews carried out with the working parents and children? What do the results disclose about the situation of today's Finnish families as they struggle between work-related and family-related expectations?

The research data was of a comparatively small sample but still reveals something about the everyday life of Finnish families. When comparing the answers of the parents and children interviewed in this research with previous studies, a relatively coherent picture of a demanding everyday life is created. The participants in this research were parents and children whose everyday life included parents with full-time jobs and children rotating between home and daycare center. According to the results, although paid work incurred conflicts in everyday life, it also supported the families and parenthood. The parent/child relationship is an entity where all areas of life interact 
with each other. According to Rönkä et al. (2009), work sets a rhythm for everyday life; similarly, the search for economic subsistence and security, a parent's need for development, the company of other adults in the workplace, and maintaining professional skills support parenthood. A refreshed parent can be a better parent for their children. Economic security, for its part, creates a relaxed atmosphere in a family whereas a shortage of money induces stress for parents and tension in the atmosphere of the family.

The results of this study could be complemented by or compared with, for example, interviews with those families that are able to take care of children in the home when the children are small. These families do not necessarily have the best financial standing but may content themselves with a more moderate and lower living standard in exchange for more time spent with their children in the early years of life.

\section{Elaborating the Research Method}

An interview situation always includes several issues that the researcher has to consider beforehand, whether the interviewee is an adult or a child. Adults are accustomed to or comfortable with producing information about their families but the children are less so. When it comes to interviewing children, one does not necessarily know how to ask questions in a child-like way: What the child's life is like, what the child's experiences are like, and what acting in the child's position is like (Alanen, 2009). In this study during the first interviews, some of the interview questions seemed to represent an adult-centered point of view; these questions were not of importance in a child's world. Drawing up questions suitable for the children was challenging because as an adult, the researcher saw the world quite differently than a child.

An interview can be considered as a researcher-dependent method of collecting data. This feature is emphasized when conducting a study by interviewing children. In every interview, a researcher enters the foreign land where the interviewee decides how far they will travel and how profoundly the experiences will be discussed. Reaching other people's experiences always demands consideration and humility but these features become particularly important when doing child interviews (Perttula, 1995; Rauhala, 2005).

Academic research does not always favor the equal relationship between a researcher and a research subject. A non-verbal expression, such as a look or smile, is an important way by which a child can be supported in an interview situation. It is important that a researcher express both by non-verbal and verbal communication that he or she really wants to listen to the child and hear what the child has to say. Generally, a fluent and democratic dialogue is based on equality and respect. Then, both child and adult have the space to elicit their thoughts and contemplations in turn. A research interview should resemble as much as possible an everyday conversation. The word "chitchat" could describe the spirit of an interview during which the conversation moves on by a dialogic and equal interaction between a child and an adult. The adult's active and intensive listening influences the child's will to carry on the dialogue (e.g., Samuelson, 2005).

A child's point of view often remains in the background when the image of the child becomes erroneous and one-sided. An adult's perspective is differently emphasized than that of a child's. Children's experiences are left in the background, are thought to be less important. In this study, by contrast, the purpose was to bring the children's experiences together with those of the adults, and give as much space as possible to all their voices. 


\section{Discussion}

Finland has a high standard of living, a well-established educational system, and a high level of technology. Both women and men actively participate in working life. This is manifested in a high gross domestic product and standard of living. This reality raises these questions: How does this success appear from the point of view of families' everyday life? Who takes care of everyday life and children's well-being?

Working life and parental work schedules interfere with the responsibilities of parenthood. In Finland, one of the present government's aims is to encourage more equal use of family leaves between women and men, referring to a so-called 6+6+6 model according to which fathers and mothers take turns being at home with their children. This is rooted in the idea of strengthening the likelihood of fathers taking a family leave. What possibilities promote the sharing of the family leaves or contemplate the practice of part-time work? Parents' freedom of choice is restricted by workplace culture, society's conceptions of acceptable solutions, and differences in the wages of women and men, as well as prevailing models of the distribution of work within families.

Unfortunately, a corporate employee who has been on an extended family leaves gets fired or laid off more easily. In public discourse, a father having a family leave is considered as "a hero". On the other hand in Finland, a woman has to make excuses if she, for example, wants to resign from a secretary's position. The threat is that the inequality between women and men will continue growing if bending the working hours and work tasks rely just on women despite the nominal opportunities provided by the state discussed at the beginning of this article.

The weekly working hours conform to the phases of life to a certain extent. In Finland, the parents are entitled to cut their working hours until their child completes Grade 2. However, parttime work has not been regularized in Finnish working life, especially with respect to gender division, in the same way as in Sweden and the proportion of those Finnish parents who work parttime or reduced hours is relatively small. The reason for this originates from the 1960s when mothers increasingly started to work in Finland. Therefore, those families with housewives and male breadwinners remained more unusual than elsewhere in Europe (e.g., Aaltio-Marjosola, 2001; Hoschild, 2000).

Part-time work would make it possible to have more relaxed everyday life and to enjoy the positive aspects of work. Part-time work provides more time, more flexibility, and perhaps more strength to confront the challenges that accompany a child's development. In addition, it may have a positive influence on the parents' mutual relationship. Nevertheless, part-time work also affects a family's income level.

Employers and labor market organizations have not noticed the effect their policies may have on child rearing: These institutions have not historically wanted to cut parents' daily working hours. Government laws no longer control working hours because the corporate and organizational culture now has a central role in determining work schedules. The enterprise sector would need new mechanisms for arranging working hours that cater to people's changing life situations. On average, the weekly working hours have increased (for example, administrative employees work approximately 48 hours per week). Later in life, a parent might feel guilty for having to work long hours when the children are small, even if he or she really wanted to work reduced hours and spend more time with the children. 
A new phenomenon has occurred within the last 15 years in Finland, namely concern for the permanency of work. Labor markets have become insecure and temporary jobs are common, primarily among young women. The culture in enterprises and organizations can be rough. When returning to work from a maternity leave, a woman's work may have been given to another employee or her position may even have been axed while she has been taking care of her baby at home. At the legislative level, employees' protections should be strengthened because the children are our future.

The family's everyday life and the time parents and children spend together have become more and more scheduled during the last 100 years. Parents and children spend time together on holidays and weekends. However, the demand for evening, weekend, and nighttime care has increased both in big and small cities. Will it be positive for child development if the need for daycare is totally dependent on the demands of working life? In addition, stores in Finland are now permitted to open on Sundays complicating children's daycare arrangement for more parents, particularly the parents of school-aged children. There are no daycare possibilities for school-aged children on weekends, a problem that is especially acute for single parents.

The complications of everyday life and the potential solutions discussed in this article concern the whole society and its future. All the stress and anxiety at work are transmitted to a child's everyday life. Children are aware that a parent's paid work requires energy and attention that could be used when playing and being together with them. Work becomes a so-called third party, not only in a relationship between parents, but also in the relationship between parent and child. An intense working pace and the overall speeding up of modern life make one wonder whether parents have enough time, strength, and energy to be together with their children. Do they have the strength and time to listen to a child's everyday joys and sorrows after work? If the shared time between a parent and a child remains minimal, the danger is that a parent pulls away from a child's everyday life and feelings. Perhaps by asking, "How are you doing?" every now and then a parent can secure a child's well-being in everyday life. 


\section{References}

Aaltio- Marjosola, I. (2001). Naiset, miehet, johtajuus [Men, women, leadership]. Vantaa, Finland: Tummavuoren Kirjapaino Oy.

Alanen, L. (2009). Johdatus lapsuudentutkimukseen [Introduction to the childhood studies]. In L. Alanen \& K. Karila (Eds.), Lapsuus, lapsuuden instituutiot ja lasten toiminta [Childhood, the institutions of the childhood, and the children's action] (pp. 9-30). Tampere, Finland: Vastapaino.

Barling, J. (1994). Work and family: In search of more effective intervention strategies. In C. L. Cooper \& D. Rousseau (Eds.), Trends in organizational behaviour (Vol. 1, pp. 63-73). London: Wiley.

Barnett, R. C., \& Hyde, J. S. (2001). Women, men, work, and family. An expansionist theory. American Psychologist, 56(10), 781-796.

Blom, R. (2001). Yhteiskunnan rakennemuutos ja perheiden elinehdot [The structural change in the society and family living conditions]. In I. Järventie \& H. Sauli (Eds.), Eriarvoinen lapsuus [Unequal childhood] (pp. 171-191). Porvoo, Finland: WSOY.

Bowes, J. (1998). Parents’ work and family roles: Their contribution to children`s learning about work. Early Childhood, 23(3), 41-45.

Bronfenbrenner, U. (1979). The ecology of human development. Experiments by nature and design. New York: Harvard University Press.

Bronfenbrenner, U. (2001). Ekologisten järjestelmien teoria [Ecological systems theory]. In V. Roos (Ed.), Kuusi teoriaa lapsen kehityksestä [Six theories of child development] (pp. 221287). Helsinki: Unipress.

Clark, S. C. (2000). Work/family border theory: A new theory of work/family balance. Human Relations, 53(6), 747-770.

Daly, K. (2003). Family theory versus the theories families live by. Journal of Marriage and Family, 65(4), 771-784.

Donati, P. (2000). The concepts and strategies for a new social policy. In H. Cavanna (Ed.), The new citizenship of the family: Comparative perspectives (pp. 140-171). Aldershot, UK: Ashgate.

Dunom, W. (2000). Recent trends and new prospects for a European family policy. In H. Cavanna (Ed.), The new citizenship of the family: Comparative perspectives (pp. 120-139). Aldershot, UK: Ashgate.

Felski, R. (2000). The invention of everyday life. New Formations: A Journal of Culture/Theory/Politics, 39, 15-31. 
International Journal of Child, Youth and Family Studies (2012) 1: 46-64

Freeman, C., \& Louca, F. (2001). As time goes by: From the industrial revolution to the information revolution. Oxford: Oxford University Press.

Frone, M. R. (2003). Work-family balance. In J. Campbell Quick \& L. E. Tetrick (Eds.), Handbook of occupational health psychology (pp. 143-162). Washington, DC: American Psychological Association.

Gadamer, H.-G. (2004). Hermeneutiikka. Ymmärtäminen tieteissä ja filosofiassa [The Hermeneutics: Comprehension in sciences and philosophy]. Tampere, Finland: Vastapaino.

Gillis, J. R. (2003). Childhood and family time: A changing historical relationship. In A.-M. Jensen \& L. McKee (Eds.), Children and the changing family. Between transformation and negotiation (pp. 149-164). London: Routledge Falmer.

Giorgi, A. (1994). A phenomenological perspective on certain qualitative research methods. Journal of Phenomenological Psychology, 25(2), 190-220.

Gottman, J. (1994). What predicts divorce? The relationships between marital process and marital outcomes. Hillsdale, NJ: Erlbaum.

Gottman, J. (1999). The seven principles for making marriage work. New York: Crown Publishers.

Haverinen, L., \& Martikainen, M. (2004). Rakas lapsi - ei. Kodin kasvattava vuorovaikutus [Dear child - No. The educative interaction at home]. Helsinki: University of Helsinki.

Hayes, A., \& Watt, M. (1998). Work and family life: Contemporary realities, current expectations and future prospects. Early Childhood, 23(3), 33-39.

Heinämäki, L. (2008). Early childhood education in Finland. Potsdam: Liberales Institut. Retrieved from http://pro-kopf.de/fileadmin/Downloads/OC_39-Heinaemaeki-ECE_in_Finland.pdf

Hoschild, A. R. (2001). The time bind. When work becomes home and home becomes work. New York: Henry Holt and Company.

Hujala, E., \& Kyrönlampi-Kylmänen, T. (2003). Päivähoitolapsen perhe - muutoksen suuntia [The family of a child who goes to day care - the directions of change]. Oulu, Finland: University of Oulu.

Jallinoja, R. (2000). Perheen aika [The family time]. Helsinki: Otava.

Jokinen, E. (2005). Aikuisten arki [Adults’ everyday life]. Helsinki: Gaudeamus.

Karney, B., \& Bradbury, T. N. (1995). The longitudinal course of marital quality and stability: A review of theory, method and research. Psychological Bulletin, 118(1), 3-34.

Klein, D., \& White, J. (1996). Family theories: An introduction. London: SAGE. 
Klein, W., Izquierdo, C., \& Bradbury, T. (2007). Working relationships: Communicative patterns and strategies among couples in everyday life. Qualitative Research in Psychology, 4(1-2), 29-47.

Korvela, P. (2003). Yhdessä ja erikseen. Perheenjäsenten kotona olemisen ja tekemisen dynamiikka [Together and separately. The dynamics of the family members being and doing at home]. Saarijärvi, Finland: Gummerus.

Korvela, P., \& Keskinen, S. (2008). From surviving to reconciling home and work: An activitytheoretical study on the art and skills in the changing everyday life of families. In T. TuomiGröhn (Ed.), Reinventing art of everyday making (pp. 253-284). Bern: Peter Lang.

Kyrönlampi-Kylmänen, T. (2007). Arki lapsen kokemana. Eksistentiaalis-fenomenologinen haastattelututkimus [Everyday life from the point of view of the child: Insights from existential phenomenological interviews] (Acta Universitatis Lapponiensis No. 111). Rovaniemi, Finland: University of Lapland.

Kyrönlampi-Kylmänen, T., \& Määttä, K. (2011). What is it like to be at home - the experiences of 5- to 7-year-old Finnish children. Early Child Development and Care.

DOI:10.1080/03004430.2010.540013

Lainiala, L. (2010). Perhepolitiikan uudet tuulet - Perheen paluu. Perhebarometri 2010 [The new trends in family policy - the return of a family. Family barometer 2010]. (The Population Research Institute, Reports E No. 39). Helsinki: The Family Federation.

Lammi-Taskula, J., Salmi, M., \& Parrukoski, S. (2009). Työ, perhe ja tasa-arvo [Work, family and equality]. Helsinki: Ministry of Social Affairs and Health.

Latomaa, T. (2005). Fenomenologinen kokemuksen tutkimus: Haastattelu, analyysi ja ymmärtäminen [Phenomenological research on experience: The interview, analysis and understanding]. In J. Perttula \& T. Latomaa (Eds.), Kokemuksen tutkimus. Merkitys Tulkinta - Ymmärtäminen [Research on experiences. Meaning - Interpretation Understanding] (pp. 163-195). Tartu, Finland: Dialogia.

Leiter, M., \& Durup, M. (1996). Work, home and in-between: A longitudinal study of spillover. The Journal of Applied Behavioral Science, 32(1), 29-47.

Michel, J. S., \& Hargis, M. B. (2008). Linking mechanisms of work-family conflict and segmentation. Journal of Vocational Behavior, 73(3), 509-522.

Määttä, K. (2005). Avioeron tuska ja helpotus [The pain and relief of divorce]. Helsinki: Tammi.

Määttä, K. (2006). Kestävä parisuhde [Long marital relationships]. Porvoo, Finland: WSOY.

Näsman, E. (2003). Employed or unemployed parents: A child perspective. In A.-M. Jensen \& L. McKee (Eds.), Children and the changing family. Between transformation and negotiation (pp. 46-60). London: RoutledgeFalmer. 
International Journal of Child, Youth and Family Studies (2012) 1: 46-64

Official Statistics of Finland. (2009). Helsinki: The social insurance institution. Retrieved from http://www.kela.fi/it/kelasto/kelasto.nsf/alias/Perhe_09_pdf/\$File/Perhe_09.pdf?OpenEleme $\underline{\text { nt }}$

Paajanen, R. (2007). Mikä on minun perheeni? Suomalaisten käsityksiä perheestä vuosina 2007 ja 1997 [What is my family? The Finnish people’s conceptions of family in 2007 and 1997]. Helsinki: The Family Federation.

Perlow, L. A. (1997). Finding time. How corporations, individuals, and families can benefit from new work practices. New York: Cornell University Press.

Perlow, L. A. (1999). The time famine: Towards a sociology of work time. Administrative Science Quarterly, 44, 57-81.

Perttula, J. (1995). Kokemus psykologisena tutkimuskohteena: johdatus fenomenologiseen psykologiaan [An experience as a target of a research: The basics of phenomenological psychology]. Tampere, Finland: The Finnish Phenomenological Institution.

Pulkkinen, L. (2002). Mukavaa yhdessä. Sosiaalinen alkupääoma ja lapsen sosiaalinen kehitys [Nice time together. Social capital and psychological development of a child]. Jyväskylä, Finland: PS-kustannus.

Rauhala, L. (2005). Hermeneuttisen tieteenfilosofian analyyseja ja sovelluksia [The analyses and applications of the hermeneutic philosophy of science]. Helsinki: University Press.

Reuna, V. (1999). Vanhemmuutta toteuttamassa [Executing parenthood]. (The Population Research Institute, Reports E No. 7). Helsinki: The Family Federation.

Rönkä, A., \& Korvela, P. (2009). Everyday family life: Dimensions, approaches, and current challenges. Journal of Family Theory \& Review, 1, 87-102.

Rönkä, A., Laitinen, K., \& Malinen, K. (2009). Miltä arki tuntuu? In A. Rönkä, K. Malinen, \& T. Lämsä (Eds.), Perhe-elämän paletti. Vanhempana ja puolisona vaihtelevassa arjessa [The colourfulness of family-life. Being a parent and a spouse in everyday-life] (pp. 203-221). Juva, Finland: PS-kustannus.

Rouvinen, R. (2007) Tässä työssä yhdistyy kaikki. Lastentarhanopettajat toimijoina päiväkodissa [This work combines everything - Kindergarten teachers as actors in the kindergarten]. Joensuu, Finland: University of Joensuu.

Samuelsson, I. P. (2005). How do children tell us about their childhoods. Early Childhood Research and Practice, 6, 1-15.

Sauli, H., \& Kainulainen, S. (2001) Yhteiskunnan muutos ja lapsiperheet [The societal change and families with children]. In M. Törrönen (Ed.), Lapsuuden hyvinvointi. Yhteiskuntapoliittinen puheenvuoro [The wellbeing in childhood. A sociopolitical speech] (pp. 42-57). Vantaa, Finland: Tummavuoren kirjapaino. 
International Journal of Child, Youth and Family Studies (2012) 1: 46-64

Scott, S. (2009). Making sense of everyday life. Cambridge, UK: Polity Press.

Sevon, E. (2009). Maternal responsibility and changing relationality at the beginning of motherhood. Jyväskylä, Finland: University of Jyväskylä.

Siren-Tiusanen, H., \& Tiusanen, E. (2001). Päivärytmi ja toiminnan rakentuminen [The daily rhythm and organizing activities]. In A. Helenius, K. Karila, H. Munter, P. Mäntynen, \& H. Siren-Tiusanen (Eds.), Pienet päivähoidossa. Alle kolmivuotiaiden lasten varhaiskasvatuksen perusteita [Small children in day care. The basics of the education of under three-year-old children] (pp. 65-89). Helsinki: WSOY.

Stern, D. (1997). Maailma lapsen silmin -mitä lapsi näkee, kokee ja tuntee [The world in a way a child sees and feels it]. Juva, Finland: WSOY.

Sternberg, R. (1999). Love is a story: A new theory of relationships. Oxford: Oxford University Press.

Tuomi-Gröhn, T. (2009). Kodin arki ja arjen taidot tutkimuskohteena [The everyday life at home and daily skills as a research target]. In H. Janhonen-Abruquah (Ed.), Kodin arki. [Everyday life at home] (pp. 147-157). Helsinki: University of Helsinki.

Uusiautti, S. (2008). “Tänään teen elämäni parhaan työn” Työmenestys Vuoden Työntekijöiden kertomana [“Today I'll work better than ever”. Employees of the year describe their experiences of success at work]. (Acta Universitatis Lapponiensis No. 138). Rovaniemi, Finland: University of Lapland.

Uusiautti, S., \& Määttä, K. (2010, accepted). The successful combination of work and family in Finland: The ability to compromise as a key factor. Journal of Comparative Family Studies.

van Manen, M. (2002). Care-as-worry, or “Don`t Worry be Happy”. Qualitative Health Research: An International, Interdisciplinary Journal, 12(2), 264-280.

Williams, B., Sawyer, S. C., \& Wahlstrom, C. M. (2005). Marriages, families \& intimate relationships. Boston: Pearson.

Wintersberger, H. (2000). Childhood perspectives and policies. In H. Cavanna (Ed.), The new citizenship of the family. Comparative perspectives (pp. 173-190). Aldershot, UK: Ashgate. 